\title{
Hydrochemical regime and its mechanism in Yamzhog Yumco Basin, South Tibet
}

\author{
ZHE Meng ${ }^{1,2},{ }^{*}$ ZHANG Xueqin ${ }^{1}$, WANG Buwei ${ }^{1,2}$, SUN Rui ${ }^{3}$, ZHENG Du ${ }^{1}$ \\ 1. Key Laboratory of Land Surface Pattern and Simulation, Institute of Geographic Sciences and Natural \\ Resources Research, CAS, Beijing 100101, China; \\ 2. University of Chinese Academy of Sciences, Beijing 100049, China; \\ 3. Rubber Research Institute, Chinese Academy of Tropical Agriculture Sciences, Danzhou 571737, Hainan, \\ China
}

\begin{abstract}
The hydrochemistry of alpine lakes reflects water characteristic and its response to climatic change. Over 300 water samples had been collected from 52 sites of 5 lakes and 7 inflowing rivers in the Yamzhog Yumco Basin, South Tibet, during 2009-2014, basing which the hydrochemical regime and its mechanism were analyzed along with the adoption of hydrological investigations in 1979 and 1984 as well. Results revealed that the waters were hard with weak alkalinity for the Yamzhog Yumco Basin. Most of them were fresh, and the rest were slightly saline. The hydrochemical types of 5 lakes (i.e., Lake Yamzhog Yum Co, Puma Yum Co, Bajiu Co, Kongmu $\mathrm{Co}$, and Chen $\mathrm{Co}$ ) were $\mathrm{SO}_{4}{ }^{2-}-\mathrm{HCO}_{3}{ }^{-}-\mathrm{Mg}^{2+}-\mathrm{Na}^{+}, \mathrm{HCO}_{3}{ }^{-}-$ $\mathrm{SO}_{4}{ }^{2-}-\mathrm{Mg}^{2+}-\mathrm{Ca}^{2+}, \mathrm{SO}_{4}{ }^{2-}-\mathrm{Mg}^{2+}-\mathrm{Na}^{+}, \mathrm{SO}_{4}{ }^{2-}-\mathrm{HCO}_{3}{ }^{-}-\mathrm{Ca}^{2+}$, and $\mathrm{SO}_{4}{ }^{2-}-\mathrm{Na}^{+}-\mathrm{Mg}^{2+}-\mathrm{Ca}^{2+}$, respectively. As for rivers, $\mathrm{HCO}_{3}{ }^{-}$and $\mathrm{SO}_{4}{ }^{2-}$ were the major anions, and $\mathrm{Ca}^{2+}$ was the dominant cation. Lake Yamzhog Yum Co, the largest lake in the basin, exhibited remarkable spatial variations in hydrochemistry at its surface but irregular changes with depth. The weathering of evaporates and carbonates, together with evaporation and crystallization, were the major mechanisms controlling the hydrochemistry of waters in the Yamzhog Yumco Basin. Global warming also had significant impacts on hydrochemical variations.
\end{abstract}

Keywords: hydrochemical regime; control mechanism; Piper diagram; Gibbs model; Yamzhog Yumco Basin; alpine lake

\section{Introduction}

The Tibetan Plateau (TP), famous as "the Roof of the World" and "the Asian Water Tower", consists of more than 1200 alpine lakes with a surface area $>1 \mathrm{~km}^{2}$ that feed several large Asian rivers (Zhou et al., 2010; Song et al., 2014a; Zhang et al., 2014a) and are highly sensitive to climatic change (Immerzeel et al., 2010; Zhu et al., 2010c; Song et al., 2014c; Yan and Zheng, 2015). With the rapid warming over the TP during the past decades (Kang et al.,

Received: 2016-07-14 Accepted: 2017-02-24

Foundation: National Natural Science Foundation of China, No.41471064, No.41171062

Author: Zhe Meng (1989-), PhD Candidate, specialized in hydrological process of alpine lakes.

E-mail: aimierzhe@126.com

*Corresponding author: Zhang Xueqin (1971-), PhD, specialized in climatic change and its effects.

E-mail: zhangxq@igsnrr.ac.cn 
2010; Li, 2014), plenty of lakes supplied mainly by glacial melt have expanded and been desalted owing to the increasing river inflow, while a number of lakes supplied mainly by precipitation have shrunk and been salted due to the intensified evaporation (Bianduo et al., 2009; Huang et al., 2011; Zhang et al., 2011, 2014b; Song et al., 2014b), both of which have led to serious social and ecological problems.

Hydrochemical analysis is an effective approach to reveal the water evolution influenced by environmental changes and anthropogenic perturbations (Wang et al., 2013), providing important clues to the compositions and water-rock interactions of basin waters (Lerman et al., 1995; Wang and Dou, 1998). The hydrochemistry of waters in the TP have been widely analyzed recently (Zhang et al., 2008; Zheng and Liu, 2009; Xiao et al., 2012a; Jiang et al., 2015; Tian et al., 2015; Yao et al., 2015; Wu, 2016). With respect to the Yamzhog Yumco Basin (YYB), significant achievements have been made on hydrochemical environment and its spatial variation (Chen, 1990; Zhu et al., 2010a; Sun et al., 2012a), as well as the chemical ions and its control factors (Zheng et al., 2008; Zhu et al., 2010b; Sun et al., 2012b). While limited by the harsh field conditions, previous observation records lasting for one year or a few months were insufficient for disclosing the long-term hydrochemical characteristics of alpine lakes. Further research is indispensable to improve the spatio-temporal resolution of hydrochemical monitoring, consequently the spatial distribution and temporal evolution of hydrochemistry can be investigated thoroughly. This paper, therefore, attempts to give a relatively integrated spatio-temporal regime of hydrochemistry, and to explore its mechanism by analyzing more than 300 water samples coming from 5 lakes and 7 rivers in the YYB during 2009 to 2014. Historical data in 1979 (Guan et al., 1984) and 1984 (Chen, 1990) were also utilized to discuss the hydrochemical evolution of the YYB. The results will hopefully deepen the understanding of water variation and its relationship with climatic change over the TP.

\section{Materials and methods}

\subsection{Study area}

The YYB $\left(90^{\circ} 06^{\prime}-91^{\circ} 41^{\prime} \mathrm{E}, 28^{\circ} 08^{\prime}-29^{\circ} 13^{\prime} \mathrm{N}\right)$, covering an area of about $9064 \mathrm{~km}^{2}$ with an average elevation of $4500 \mathrm{~m}$ above sea level (Zhang et al., 2012), is the largest closed lake basin in south Tibet (Figure 1). Located in Langkazi and Gongga counties, Shannan Prefecture, Tibet, the northern basin is separated by Ganbala Mountain from the Yarlung Zangbo River, the southern basin is bounded by Mengdagangri Snow Mountain, the western basin borders Nianchu River Basin with the Karola Glacier as the watershed, and the eastern basin is adjacent to the Zheguco Basin (Guan et al., 1984). With the alpine bush-steppe semiarid climate in south Tibet, the annual average temperature and precipitation in the YYB were $2.9^{\circ} \mathrm{C}$ and $365.7 \mathrm{~mm}$, respectively according to the monthly observations of Langkazi Meteorological Station during 1961-2014. The annual average water surface evaporation was $1219.6 \mathrm{~mm}$ according to the daily observations of Baidi Hydrological Station during 1975-2014. Accompanied with sparsely scattered small arbors, the main vegetation type in the YYB, namely, the meadow is composed by Gramineae, Compositae, and Ranunculaceae (Yu et al., 2010). Livestock husbandry is the dominant human activity for the YYB. Tourism is also playing an increasingly important role in local economic development. 


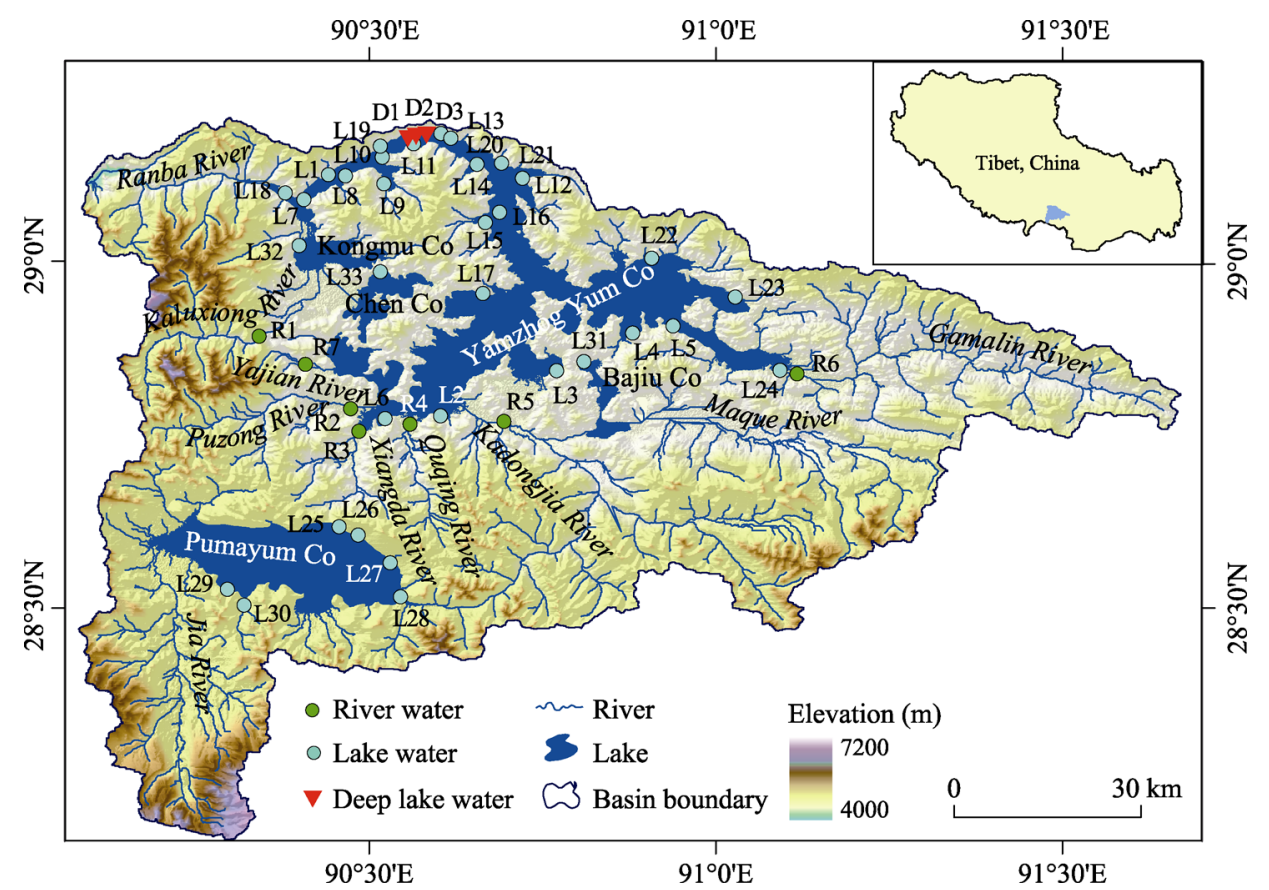

Figure 1 Map of the YYB and sampling locations. It is based on the digital elevation model (DEM) with a ground resolution of $90 \mathrm{~m}$, which was obtained from the NASA SRTM (http://srtm.csi.cgiar.org/)

Major lakes in the YYB include Lake Yamzhog Yum Co, Kongmu Co, Chen Co, Bajiu Co, and Puma Yum Co. As one of the holy lakes in Tibet, Lake Yamzhog Yum Co $\left(90^{\circ} 22^{\prime}-\right.$ $91^{\circ} 03^{\prime} \mathrm{E}, 28^{\circ} 27^{\prime}-29^{\circ} 12^{\prime} \mathrm{N}$ ) is the largest inland lake on the northern foothills of the Himalayas with a water surface of about $588.9 \mathrm{~km}^{2}$ (Sun et al., 2013a). Supplied mainly by precipitation, the lake level has dropped significantly since 1974 (Ye et al., 2007; Chu et al., 2012; Li, 2014). There are 7 major inflowing rivers around the lake, i.e., Gamalin River, Kadongjia River, Quqing River, Xiangda River, Puzong River, Kaluxiong River, and Yajian River (Figure 1). Located about $40 \mathrm{~km}$ southward from Lake Yamzhog Yum Co, Lake Puma Yum Co $\left(90^{\circ} 13^{\prime}-91^{\circ} 33^{\prime} \mathrm{E}, 28^{\circ} 30^{\prime}-28^{\circ} 38^{\prime} \mathrm{N}\right)$ is the second largest lake in this basin with an area of about $285.7 \mathrm{~km}^{2}$ (Tian et al., 2012). The Jia River, accounting for $77 \%$ of the total inflow into the Lake Puma Yum Co, is sourced from the glacial melt in the southwestern part of the basin (Zhu et al., 2006). An open channel connected to the Kadongjia River was excavated on the lake's eastern side, through which the water drained into Lake Yamzhog Yum Co during high lake level period.

\subsection{Sampling and testing}

Water samples were field collected annually in the YYB from 2009 to 2014. A total of 52 sampling sites were set in this basin (Figure 1), comprising 24 surface water sites and 12 deep water sites $(0.5 \mathrm{~m}, 10 \mathrm{~m}, 20 \mathrm{~m}$, and $30 \mathrm{~m}$, respectively, beneath the water surface along 3 profiles) in Lake Yamzhog Yum Co, 6 surface water sites in Lake Puma Yum Co, and 10 surface water sites in other 3 lakes and 7 rivers. According to the coordinates of global positioning system (GPS, Trimble Juno SB, USA) and field investigation records, sampling sites were kept as consistent as possible. In addition, historical observation data in 1979 and 1984 were extracted trying to give a whole picture of the hydrochemical evolution in the 
YYB during the past dacades.

All the water samples were collected using pre-washed high-density polyethylene (HDPE) bottles wrapped with parafilm immediately after sample collection. Parameters including water temperature $(T), \mathrm{pH}$, and total dissolved solids (TDS) were measured in situ by utilizing a multi-parameter water probe sensor (HANNA HI9828, Italy). While hydrochemical ions were tested in the laboratory at the Institute of Geographic Sciences and Natural Resources Research (IGSNRR), Chinese Academy of Sciences (CAS), the cations of $\mathrm{K}^{+}, \mathrm{Na}^{+}$, $\mathrm{Ca}^{2+}$, and $\mathrm{Mg}^{2+}$ were measured by an inductively coupled plasma optical emission spectrometer (ICP-OES, Perkin-Elmer Optima 5300DV, USA) with a precision of $\pm 5 \%$. An ion chromatography system (ICS, Shimadzu LC-10ADvp, Japan) with the accuracy about $\pm 0.04 \%$ was adopted for the analysis of $\mathrm{Cl}^{-}$and $\mathrm{SO}_{4}{ }^{2-} \cdot \mathrm{CO}_{3}{ }^{2-}$ and $\mathrm{HCO}_{3}{ }^{-}$were titrated by double-indicator method. Mineralization degree (MD) was summed up by all major ions. And total hardness (TH) was calculated with the following equation (Maidment, 1993):

$\mathrm{TH}\left(\mathrm{mg} / \mathrm{l}\right.$ as $\left.\mathrm{CaCO}_{3}\right)=2.497 \times \mathrm{Ca}(\mathrm{mg} / \mathrm{l})+4.118 \times \mathrm{Mg}(\mathrm{mg} / \mathrm{l})$

\subsection{Analysis method}

Plotted by GW-Chart (Winston, 2000), Piper trilinear diagram (Piper, 1944) was used for elucidating the dominant ions and hydrochemical types of waters in the YYB. Distinct zones in Piper diagram display different hydrochemical facies with defined cation and anion concentrations (Cui and Li, 2014). Based on Kriging interpolation method (Stein, 1999), the contour maps of hydrochemical concentrations were drawn in ArcGIS 10.2 (ESRI, 2013) to describe the spatial variation of hydrochemical features. Meanwhile, Gibbs model (Gibbs, 1970) was introduced to reveal the natural control mechanism of hydrochemistry, namely, the influences of precipitation, rock-water interaction, and evaporation on dissolved salts in waters.

\section{Results and discussion}

Based on the annual average hydrochemical data for waters in the YYB during 2009-2014, the cationic charge $\left(\mathrm{TZ}^{+}=\mathrm{Na}^{+}+\mathrm{K}^{+}+2 \mathrm{Mg}^{2+}+2 \mathrm{Ca}^{2+}\right)$ ranged from 5.21 to $68.28 \mathrm{meq} / 1$ with the average of $33.76 \mathrm{meq} / \mathrm{l}$, and anionic charge $\left(\mathrm{TZ}^{-}=\mathrm{Cl}^{-}+2 \mathrm{SO}_{4}{ }^{2-}+\mathrm{HCO}_{3}{ }^{-}+\mathrm{NO}_{3}{ }^{-}\right)$varied from 3.36 to $63.91 \mathrm{meq} / 1 \mathrm{with}$ an average of $27.83 \mathrm{meq} / 1$ (Table 1$)$. The normalized inorganic charge balance $\left(\mathrm{NICB}=\left(\mathrm{TZ}^{+}-\mathrm{TZ}^{-}\right) / \mathrm{TZ}^{+}\right)$of all samples were about 0.18 , indicating the reliability of the data (Xiao et al., 2012b).

\subsection{Physicochemical parameters}

Waters in the YYB were weakly alkaline, with $\mathrm{pH}$ values ranging from 8.38 to 9.49 (Table 1; Figure 2a). Most waters exceeded the permitted $\mathrm{pH}$ values for drinking (6.5-8.5) stipulated by Chinese Ministry of Environmental Protection (2002). As the TH values of the Yajian River and Gamalin River were 127.32 and 174.68, respectively, they were classified as hard waters $(121<\mathrm{TH}<180 \mathrm{mg} / \mathrm{l}$; Maidment, 1993). All other waters in the YYB were the hardest water $(\mathrm{TH}>180 \mathrm{mg} / \mathrm{l})$, with $\mathrm{TH}$ values ranging from 207.05 to $1327.68 \mathrm{mg} / \mathrm{l}$ (Table 1 and Figure 2b). Specifically, the TH values of Lake Bajiu Co and Yamzhog Yum Co were higher than the recommended value of the World Health Organization (WHO) for drinking 
water $(500 \mathrm{mg} / \mathrm{l})$. In addition, the lakes were slightly saline (TDS > $1000 \mathrm{mg} / \mathrm{l}$; Maidment, 1993), with the TDS reaching 1550.67 and $1065.71 \mathrm{mg} / \mathrm{l}$ in Lake Bajiu Co and Yamzhog Yum Co, respectively (Table 1; Figure 2c). Most other waters were fresh (TDS $<1000 \mathrm{mg} / \mathrm{l})$. In particular, the relatively low TDS values of Lake Kongmu Co (209.33 $\mathrm{mg} / \mathrm{l})$ and Puma Yum Co (227.69 $\mathrm{mg} / \mathrm{l})$ were indicative of diluting effects of glacial melt on soluble salts in water, resulting from the inflow of the Kaluxiong River and Jia River, respectively. Compared with the lakes, the rivers contained lower TDS, ranging from 110.50 to 269.17 $\mathrm{mg} / \mathrm{l}$, which probably be ascribed to lower flow velocity at the river mouth, or a higher rate of evaporation in the lakes compared with the rivers. Almost all rivers in the YYB, however, contained higher TDS than the mean value of the world's rivers (115 mg/l; Gaillardet et al., 1999), which could be attributed to intense evaporation over the TP.
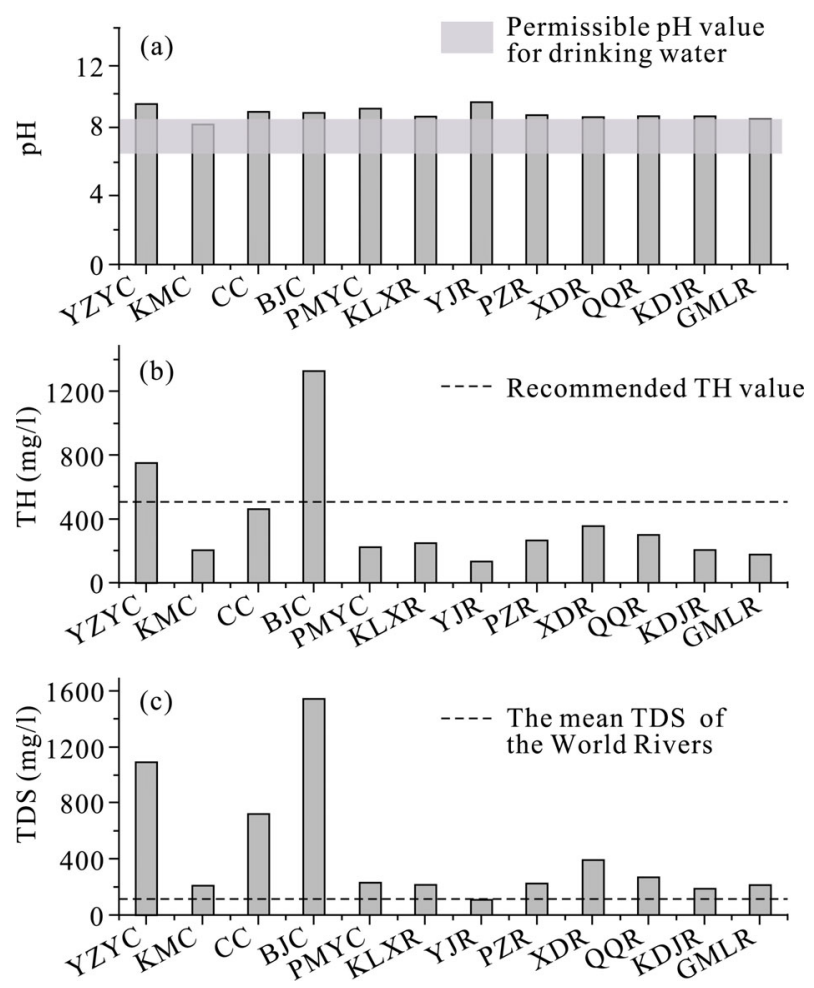

Figure 2 The annual average (a) pH, (b) TH, and (c) TDS values of waters in the YYB during 2009-2014. YZYC, KMC, CC, BJC, PMYC, KLXR, YJR, PZR, XDR, QQR, KDJR, and GMLR are short for Lake Yamzhog Yum Co, Kongmu Co, Chen Co, Bajiu Co, Puma Yum Co, Kaluxiong River, Yajian River, Puzong River, Xiangda River, Quqing River, Kadongjia River, and Gamalin River, respectively

\subsection{Hydrochemical regime}

\section{(1) For the Yamzhog Yumco Basin (YYB)}

Diversified hydrochemical types with various dominant ions were obtained in the waters of the YYB (Figure 3). $\mathrm{Mg}^{2+}$ and $\mathrm{Na}^{+}$constituted the major cations, and $\mathrm{SO}_{4}{ }^{2-}$ plus $\mathrm{HCO}_{3}{ }^{-}$ made up the major anions for waters in Lake Yamzhog Yum Co (Figure 3a), indicating its $\mathrm{SO}_{4}{ }^{2-}-\mathrm{HCO}_{3}{ }^{-}-\mathrm{Mg}^{2+}-\mathrm{Na}^{+}$type. The hydrochemical types of Lake Bajiu Co, Kongmu Co, Chen $\mathrm{Co}$, and Puma Yum Co were $\mathrm{SO}_{4}{ }^{2-}-\mathrm{Mg}^{2+}-\mathrm{Na}^{+}, \mathrm{SO}_{4}{ }^{2-}-\mathrm{HCO}_{3}{ }^{-}-\mathrm{Ca}^{2+}, \mathrm{SO}_{4}{ }^{2-}-\mathrm{Na}^{+}-\mathrm{Mg}^{2+}-\mathrm{Ca}^{2+}$, and $\mathrm{HCO}_{3}{ }^{-}-\mathrm{SO}_{4}{ }^{2-}-\mathrm{Mg}^{2+}-\mathrm{Ca}^{2+}$, respectively. While for the inflowing rivers, the hydrochemical types were $\mathrm{HCO}_{3}{ }^{-}-\mathrm{Ca}^{2+}$ and $\mathrm{SO}_{4}{ }^{2-}-\mathrm{Ca}^{2+}$ with $\mathrm{Ca}^{2+}$ concentrations accounting for more than $57 \%$ of the cations (Figure $3 \mathrm{~b}$ ), which were particularly different from that in Lake Yamzhog Yum Co and Bajiu Co. The lower $\mathrm{Ca}^{2+}$ concentrations in lakes should be related to the intense evaporation and subsequent precipitation of $\mathrm{Ca}^{2+}$ from the lake waters in the form of carbonate (Zhu et al., 2010b).

The weathering of rock material also contributes to the hydrochemical composition of water, and this contribution can be estimated from carbonate hardness, represented by the 
concentrations of $\mathrm{Mg}^{2+}$ and $\mathrm{Ca}^{2+}$ in the water, as carbonate hardness is in equilibrium with dissolved carbonates (Li et al., 2013). For the waters of Lake Puma Yum Co, Gamalin River, and Yajian River, the predominant impact factors were weathered carbonates with their carbonate hardness exceeding 50\% distributed in Zone I in Piper diagram (Figure 3). While weathered evaporates were dominating factors with non-carbonate hardness exceeding 50\% for the waters of Lake Bajiu Co, Kadongjia River, Quqing River, and Puzong River located in Zone II. Weak water-rock interactions were detected in Lake Yamzhog Yum Co, Kongmu $\mathrm{Co}$, and Chen $\mathrm{Co}$, in view of their samples situated in Zone V with no anion-cation pair exceeding 50\% (Figure 3).

(a)

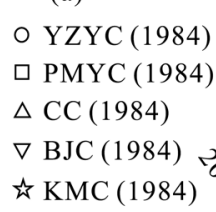

太 $\mathrm{KMC}(1984)$
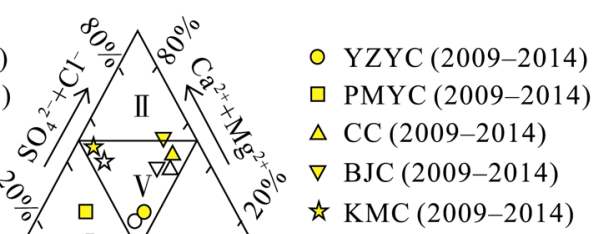

(b)

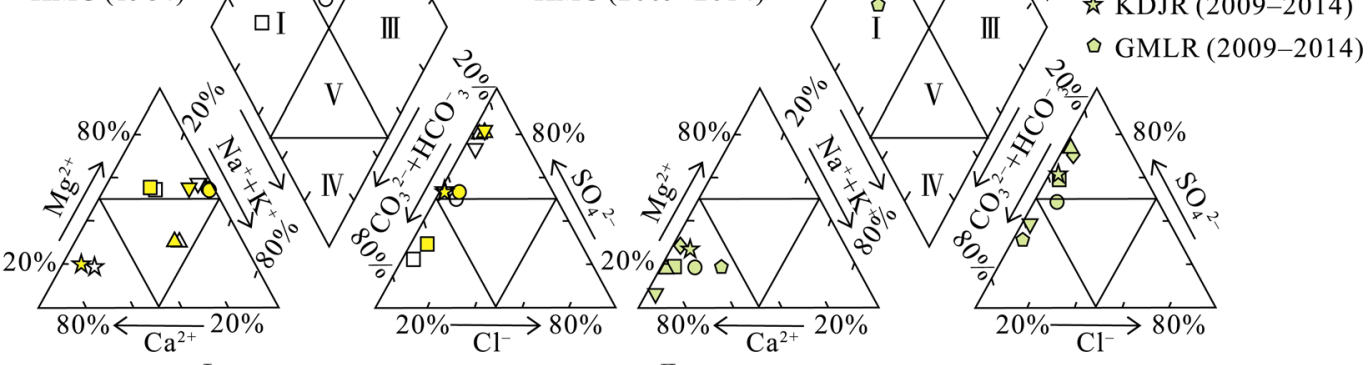

I . Carbonate hardness exceeds 50\% II . Non-carbonate Hardness exceeds $50 \%$

III. Alkalies and strong acids predominated IV. Alkaline earth and weak acids predominated V. Mixed type

Figure 3 The Piper diagrams of the major ion concentrations and hydrochemical types of waters in the YYB, showing (a) the current status (2009-2014) and the variations from 1984 in lake waters and (b) the current status (2009-2014) in river waters. Data in 1984 is after Chen (1990). YZYC, PMYC, CC, BJC, KMC, KLXR, YJR, PZR, XDR, QQR, KDJR, and GMLR are short for Lake Yamzhog Yum Co, Puma Yum Co, Chen Co, Bajiu Co, Kongmu Co, Kaluxiong River, Yajian River, Puzong River, Xiangda River, Quqing River, Kadongjia River, and Gamalin River, respectively

\section{(2) For the Lake Yamzhog Yum Co}

The complex zigzag shoreline of Lake Yamzhog Yum Co, coupled with mixed inflow from various river systems, had resulted in inhomogeneous mixing of the waters, giving rise to significant spatial differences in the hydrochemistry of its surface waters. The MD values, as well as the molar concentrations of $\left(\mathrm{Na}^{+}+\mathrm{K}^{+}\right)$and $\mathrm{Mg}^{2+}$, were low in the river mouth entering into Lake Yamzhog Yum Co (Figures $4 \mathrm{a}-4 \mathrm{c}$ ). Obviously, inflowing river water played an essential role as a diluting agent. Moreover, the narrow shape and steep northwestern lakeshore made slope runoff an important factor contributing to the low MD values in this region (Figure 4a). In contrast, higher $\mathrm{Ca}^{2+}$ molar concentrations occurred proximal to river mouths, due to the high $\mathrm{Ca}^{2+}$ values of the inflowing river waters (Figure $4 \mathrm{~d}$ ). While pervasively low $\mathrm{Ca}^{2+}$ concentrations were maintained throughout Lake Yamzhog Yum Co because of the large amount of $\mathrm{Ca}^{2+}$ precipitated in carbonates during periods of intense evaporation and concentration. These hydrochemical characteristics are similar to those of most alpine lakes on or near the TP (Ju et al., 2010). The concentrations of $\mathrm{Cl}^{-}, \mathrm{SO}_{4}{ }^{2-}$, and $\left(\mathrm{HCO}_{3}{ }^{-}+\right.$ $\mathrm{CO}_{3}{ }^{2-}$ ) ranged among $7.78 \%-8.18 \%, 52.20 \%-53.71 \%$, and $38.19 \%-39.98 \%$, respectively. 

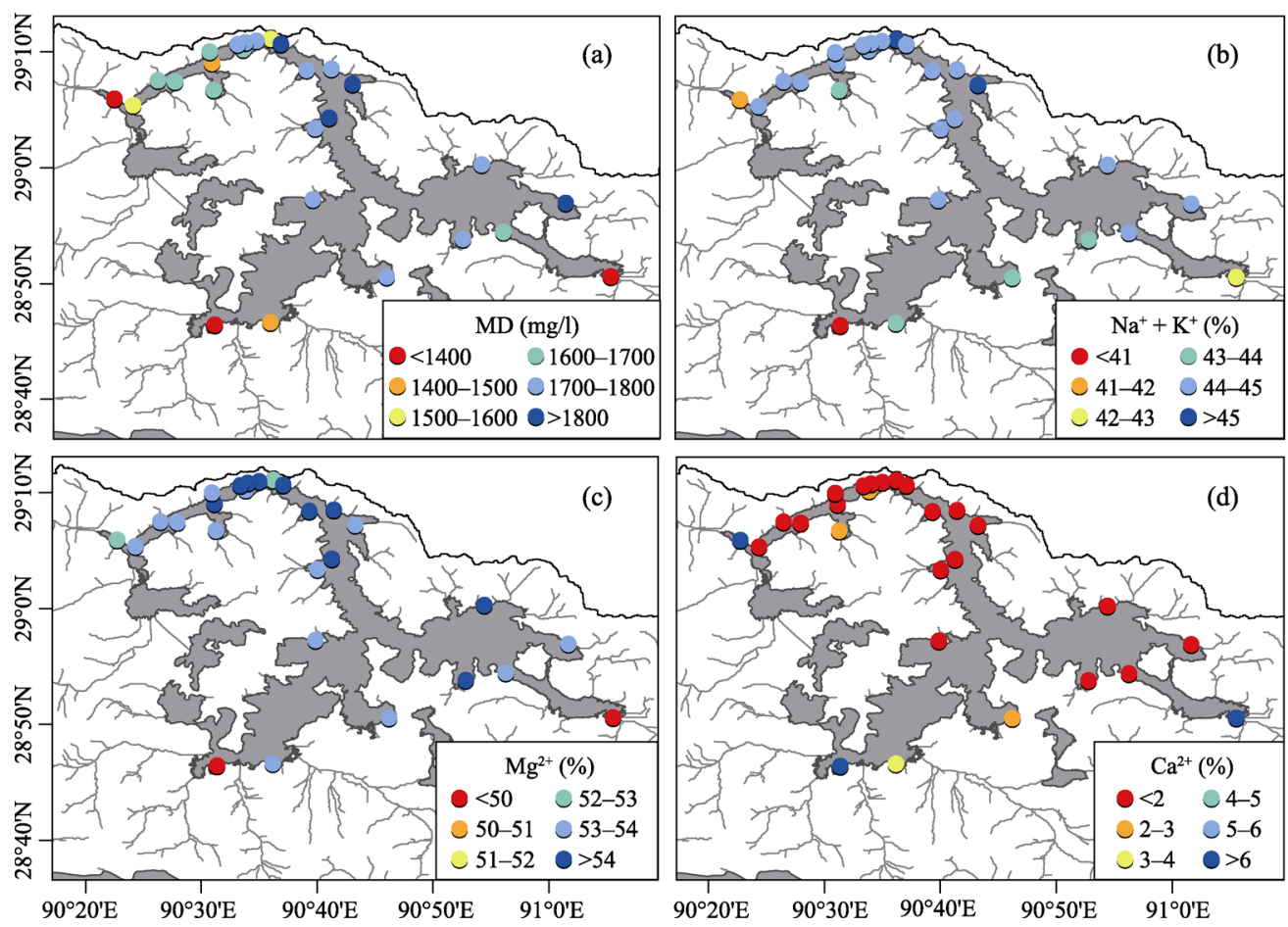

Figure 4 The spatial distribution of (a) MD values and the molar concentration percentage of (b) $\left(\mathrm{Na}^{+}+\mathrm{K}^{+}\right)$, (c) $\mathrm{Mg}^{2+}$, and (d) $\mathrm{Ca}^{2+}$ in the surface water of Lake Yamzhog Yum Co

The irregularity of hydrochemical variations with depth (Figure 5) was related to disturbances caused by strong winds over the TP, and abundant rainfall during the sampling period. Additionally, the warming climate accelerated glacial melt, resulting in less pronounced variations with water depth during 2009-2014 than was observed in 1979. In summary, waters in Lake Yamzhog Yum Co were mixed uniformly in the vertical direction, which was in agreement with the previous studies about the water spatial variation based on stable isotopes (Zang et al., 2014).

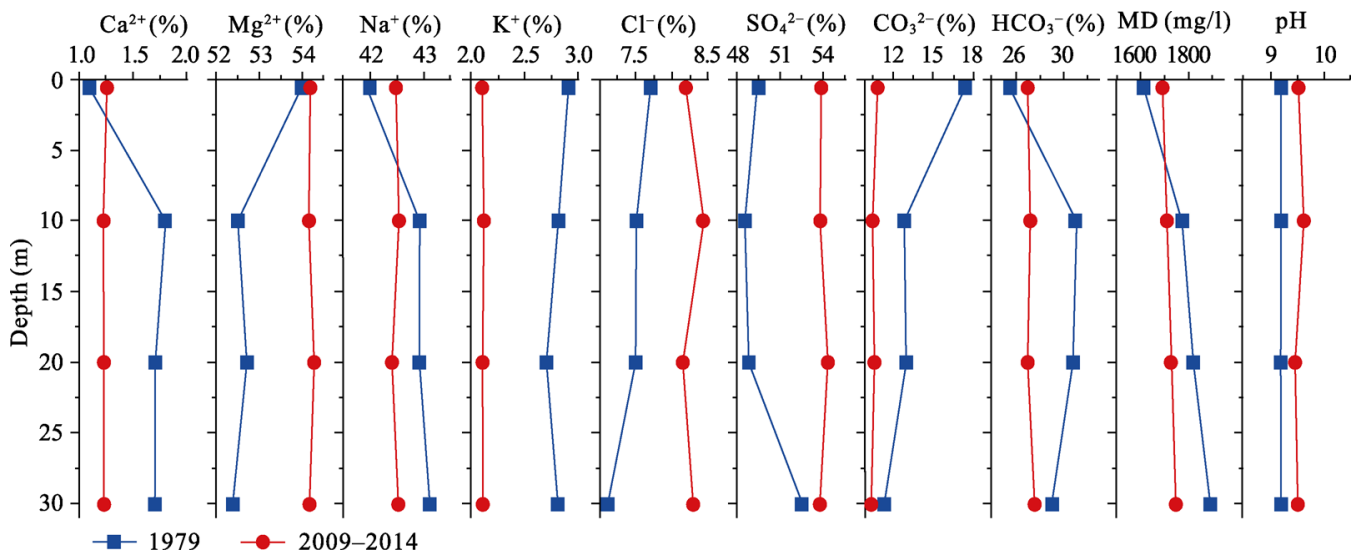

Figure 5 The vertical changes in major ions, MD, and pH values of waters in Lake Yamzhog Yum Co in 1979 and 2009-2014. Data in 1979 is after Guan et al. (1984) 


\subsection{Mechanisms controlling hydrochemistry}

Ion source and climatic change were the two primary impact factors of the hydrochemical characteristics.

(1) Source of ions

The source of hydrochemical ions was explored through a Gibbs diagram (Figure 6). Water samples from Lake Yamzhog Yum Co, Chen Co, and Bajiu Co contained relatively high TDS and yielded high $\mathrm{Na}^{+} /\left(\mathrm{Na}^{+}+\mathrm{Ca}^{2+}\right)$ values, plotting in the evaporation-crystallization zone in Figure 6. The influence of weathered rock material introduced to the lakes by inflowing rivers was likely the cause of the low $\mathrm{Cl}^{-} /\left(\mathrm{Cl}^{-}+\mathrm{HCO}_{3}{ }^{-}\right)$values, as shown by samples from Lake Kongmu Co and seven rivers, which plotted in the rock dominance zone (low TDS; Figure 6). Similar position was observed for the samples from Lake Puma Yum Co in the Gibbs diagram. Higher $\mathrm{Na}^{+} /\left(\mathrm{Na}^{+}+\mathrm{Ca}^{2+}\right)$ ratios, however, reflected the combined effects of evaporation and crystallization.
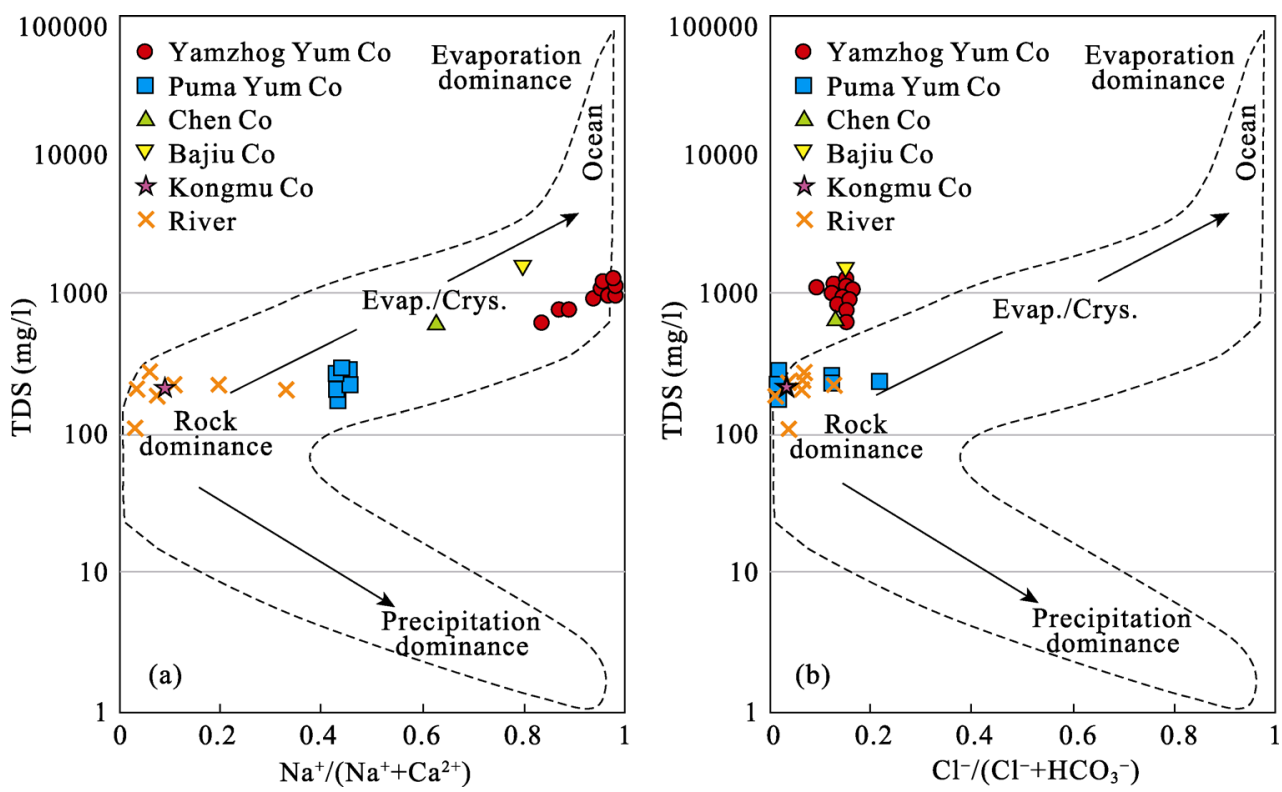

Figure 6 Gibbs diagram of TDS values versus the weight ratio of $\mathrm{Na}^{+} /\left(\mathrm{Na}^{+}+\mathrm{Ca}^{2+}\right)$ and $\mathrm{Cl}^{-} /\left(\mathrm{Cl}^{-}+\mathrm{HCO}_{3}{ }^{-}\right)$, indicating the mechanisms controlling the hydrochemistry of main lake and river waters in the YYB

As noticeable effects on the hydrochemical compositions of lake waters in the YYB, the source of ions in river waters was further analyzed. Weathered rocks are the major source of dissolved salts in river waters due to limited precipitation and waste pollution in this region (Smolders et al., 2004). 50\% of solutes in the world's rivers originate from carbonates, $17.2 \%$ from evaporates, and 11.6\% from silicates (Meybeck, 1987). The rock types that have been weathered to yield the solutes can be determined from the major ions in the waters, e.g., $\mathrm{HCO}_{3}{ }^{-}$in river waters is derived mainly from the weathered carbonates, $\mathrm{Cl}^{-}$and $\mathrm{SO}_{4}{ }^{2-}$ from evaporates, $\mathrm{Na}^{+}$and $\mathrm{K}^{+}$from both evaporates and silicates, and $\mathrm{Ca}^{2+}$ and $\mathrm{Mg}^{2+}$ may from all three of these rock types under natural conditions (Chen et al., 2002). The types of weathered rock affecting the hydrochemistry of rivers in the YYB hence were uncovered by analyzing the ratios of major ions in waters (Figure 7). Considering the relatively high concen- 
trations of $\left(\mathrm{Cl}^{-}+\mathrm{SO}_{4}{ }^{2-}\right)$ compared with $\mathrm{HCO}_{3}{ }^{-}$, solutes in the waters of Xiangda River, Quqing River, Kaluxiong River, Puzong River, and Kadongjia River were derived from weathered evaporates where they flowed above (Figure 7a). Conversely, the high $\mathrm{HCO}_{3}{ }^{-}$concentrations in the waters of Gamalin River and Yajian River indicated that ions in these waters were derived predominantly from the weathering of carbonates. Weathered evaporates constituted a source of solutes in Yajian River, which contained almost equal proportions of $\left(\mathrm{Cl}^{-}+\mathrm{SO}_{4}{ }^{2-}\right)$ and $\mathrm{HCO}_{3}{ }^{-}$. In addition, all the rivers contained almost equal proportions of $\left(\mathrm{HCO}_{3}{ }^{-}+\mathrm{SO}_{4}{ }^{2-}\right)$ and $\left(\mathrm{Ca}^{2+}+\mathrm{Mg}^{2+}\right)$ (Figure $7 \mathrm{~b}$ ), indicating that the dissolution of calcite, dolomite and gypsum could be crucial reaction in river systems. Relatively high $\left(\mathrm{Ca}^{2+}+\mathrm{Mg}^{2+}\right)$ values revealed weathered carbonates were not the primary source of ions in the river systems (Figure $7 \mathrm{c}$ ), and additional sources of $\mathrm{Ca}^{2+}$ and $\mathrm{Mg}^{2+}$ were balanced by $\mathrm{Cl}^{-}$and $\mathrm{SO}_{4}{ }^{2-}$ (Zhang et al., 2011). The greater proportion of $\left(\mathrm{Ca}^{2+}+\mathrm{Mg}^{2+}\right)$ and $\mathrm{SO}_{4}{ }^{2-}$ relative to alkalis metal ions (Figure 7d) and $\mathrm{Na}^{+}$(Figure 7e), respectively, were indicative of the influence of $\mathrm{Ca}^{2+}-\mathrm{Mg}^{2+}-\mathrm{SO}_{4}{ }^{2-}$-rich rocks (e.g., gypsum) on the hydrochemistry of river waters. The relationship between $\mathrm{SO}_{4}{ }^{2-}$ and $\mathrm{Na}^{+}$suggested mirabilite was a potential source of $\mathrm{Na}^{+}$in $\mathrm{Ga}-$ malin River owing to the coordinate relationship between $\mathrm{SO}_{4}{ }^{2-}$ and $\mathrm{Na}^{+}$(Figure $7 \mathrm{f}$ ). And halite was responsible for $\mathrm{Na}^{+}$in Puzong River, Kaluxiong River, Quqing River, and Kadongjia River, because they contained equal proportions of $\mathrm{Na}^{+}$and $\mathrm{Cl}^{-}$(Figure $7 \mathrm{f}$ ). $\mathrm{Na}^{+}$in Xiangda River was probably originated from silicates, as no correlation between $\mathrm{SO}_{4}{ }^{2-}, \mathrm{Cl}^{-}$, and other metal ions is observed.
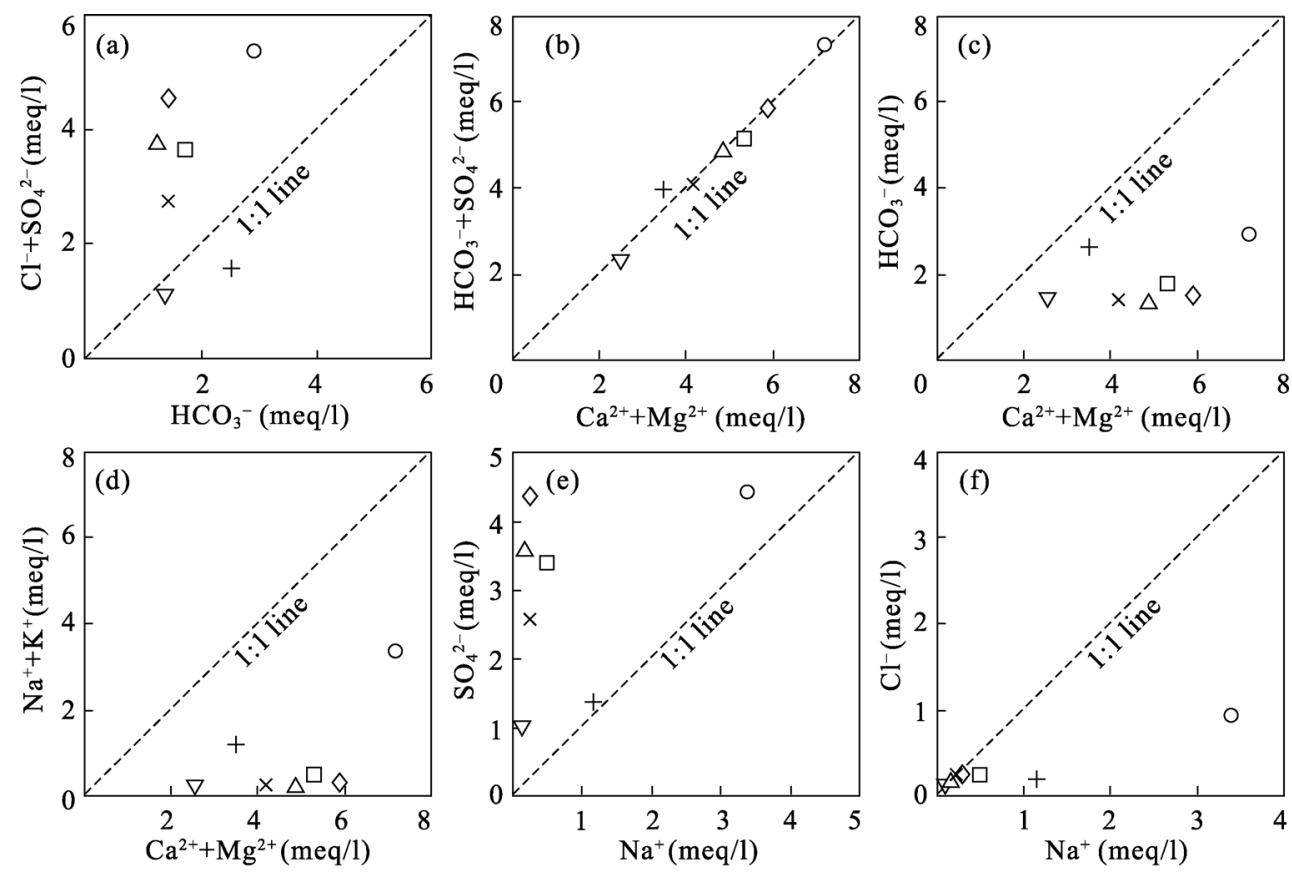

$\triangle$ Kaluxiong River $\square$ Puzong River $\nabla$ Yajian River O Xiangda River $\diamond$ Quqing River $\times$ Kadongjia River + Gamalin River

Figure 7 Scatter diagrams of (a) $\left(\mathrm{Cl}^{-}+\mathrm{SO}_{4}{ }^{2-}\right)$ vs. $\mathrm{HCO}_{3}{ }^{-}$, (b) $\left(\mathrm{HCO}_{3}{ }^{-}+\mathrm{SO}_{4}{ }^{2-}\right)$ vs. $\left(\mathrm{Ca}^{2+}+\mathrm{Mg}^{2+}\right)$, (c) $\mathrm{HCO}_{3}{ }^{-}$vs. $\left(\mathrm{Ca}^{2+}+\mathrm{Mg}^{2+}\right),(\mathrm{d})\left(\mathrm{Na}^{+}+\mathrm{K}^{+}\right)$vs. $\left(\mathrm{Ca}^{2+}+\mathrm{Mg}^{2+}\right)$, (e) $\mathrm{SO}_{4}{ }^{2-} \mathrm{vs} . \mathrm{Na}^{+}$, and (f) $\mathrm{Cl}^{-}$vs. $\mathrm{Na}^{+}$for river waters in the YYB

(2) Climatic change

Climatic change contributes to hydrochemical variations in the YYB, particularly in Lake 
Puma Yum Co. The annual average temperature and annual precipitation increased at a rate of $0.4^{\circ} \mathrm{C} / 10 \mathrm{a}$ and $22.1 \mathrm{~mm} / 10 \mathrm{a}$, respectively, between 1984 and 2014 . Compared with field hydrochemical investigations in 1984 (Chen, 1990), the salinity of Lake Puma Yum Co for the period of 2009-2014 had been decreased obviously (Zone I in Figure 3a), which should be a result of accelerated glacial melt driven by a warming climate. While both ionic compositions and hydrochemical types had changed little in the other waters of the YYB (Figure 3a), which can be explained with water balance of the closed lake system. Specifically, inflow runoff and lake-surface precipitation were the major inputs, lake evaporation was the major output, and water leakage and inaccuracy were the residuals. Sun et al., (2014) reported that variations in the water volume of Lake Yamzhog Yum Co showed no clear relationship with system outputs, but strongly correlated with inputs, including increased precipitation and melting water. In addition, underground water leakage and the operation of the Yanzhog Yumcuo Pumped Storage Power Station probably exacerbated water loss. Therefore, although evaporation was greatly enhanced under the climatic warming, little change was detected in the hydrochemical properties of the closed lake system of the YYB. To better identify the influences of climatic change on the hydrochemical regime and its mechanism of alpine lakes, more regular water sampling should be conducted at a higher spatial resolution. Moreover, future studies should focus on quantifying each component of the lake water balance.

\section{Conclusions}

Based on the long-term and large-scale field investigation, we analyzed the hydrochemical characteristics of waters in the YYB, shedding light on the hydrochemical regime and its mechanism. This research gave a whole picture of hydrochemical status in the YYB for the first time.

(1) Waters of the YYB were unsuitable for drinking due to their excessive hardness $(\mathrm{TH}>500 \mathrm{mg} / \mathrm{l})$ and alkalinity $(\mathrm{pH}>8.5)$. Most of the rivers in the basin contained higher TDS than the mean value of the world's rivers, owing to intense evaporation over the TP.

(2) Apparent differences existed in dominant ions and hydrochemical types among the waters of the YYB, most notably the much lower $\mathrm{Ca}^{2+}$ concentration in Lake Yamzhog Yum Co than that in its inflowing rivers. The loss of $\mathrm{Ca}^{2+}$ in lake could be attributed to the carbonate precipitation induced by intense evaporation. Lake Yamzhog Yum Co exhibited remarkable spatial variations in MD and the concentrations of cations for its surface waters but irregular changes in the vertical direction.

(3) The dominant mechanisms controlling the hydrochemistry of the YYB included the weathering of evaporates and carbonates and climatic change. In particular, Lake Puma Yum Co experienced marked desalination between 2009 and 2014, resulting from accelerated glacial melt induced by the dramatic warming over the TP.

\section{References}

Bianduo, Bianbaciren, Li L et al., 2009. The response of lake change to climate fluctuation in north Qinghai-Tibet Plateau in last 30 years. Journal of Geographical Sciences, 19(2): 131-142.

Chen J S, Wang F Y, Xia X H et al., 2002. Major element chemistry of the Changjiang (Yangtze River). Chemical 
Geology, 187(3): 231-255.

Chen X P, 1990. On the change of water environment in Yangzhuoyong Lake, Tibet. Oceanologia et Limnologia Sinica, 21(3): 285-293. (in Chinese)

Chu D, Pu Qiong, Labazhuoma et al., 2012. Remote sensing analysis on lake area variations of Yamzho Yumco in Tibetan Plateau over the past 40a. Journal of Lake Sciences, 24(3): 494-502. (in Chinese)

Cui B L, Li X Y, 2014. Characteristics of stable isotopes and hydrochemistry of river water in the Qinghai Lake Basin, northeast Qinghai-Tibet Plateau, China. Environmental Earth Sciences, 73(8): 4251-4263.

Du J, Hu J, Tang S J et al., 2008. Climatic variations of temperature and precipitation in the Yamzho Yumco Lake Basin of Tibet from 1961 to 2005. Acta Geographica Sinica, 63(11): 1160-1168. (in Chinese)

ESRI, 2013. ArcGIS Desktop: Release 10.2.

Gaillardet J, DupréB, Louvat $\mathrm{P}$ et al., 1999. Global silicate weathering and $\mathrm{CO}_{2}$ consumption rates deduced from the chemistry of large rivers. Chemical Geology, 159(1-4): 3-30.

Gibbs R J, 1970. Mechanisms controlling world water chemistry. Science, 170(3962): 1088-1090.

Guan Z, Chen C, Qu Y et al., 1984. Rivers and Lakes in Tibet. Beijing: Science and Technology Press. (in Chinese)

Huang L, Liu J Y, Shao Q Q et al., 2011. Changing inland lakes responding to climate warming in Northeastern Tibetan Plateau. Climatic Change, 109(3): 479-502.

Immerzeel W W, van Beek L P H, Bierkens M F P, 2010. Climate change will affect the Asian water towers. Science, 328(5984): 1382-1385.

Jiang L G, Yao Z J, Liu Z F et al., 2015. Hydrochemistry and its controlling factors of rivers in the source region of the Yangtze River on the Tibetan Plateau. Journal of Geochemical Exploration, 155: 76-83.

Ju J T, Zhu L P, Wang J B et al., 2010. Water and sediment chemistry of Lake Pumayum Co, South Tibet, China: Implications for interpreting sediment carbonate. Journal of Paleolimnology, 43(3): 463-474.

Kang S C, Xu Y W, You Q L et al., 2010. Review of climate and cryospheric change in the Tibetan Plateau. Environmental Research Letters, 5(1): 75-82.

Lerman A, Imboden D, Gat J, 1995. Physics and Chemistry of Lakes. New York: Springer.

Li P Y, Qian H, Wu J H et al., 2013. Major ion chemistry of shallow groundwater in the Dongsheng Coalfield, Ordos Basin, China. Mine Water and the Environment, 32(3): 195-206.

Li Z G, 2014. Glacier and lake changes across the Tibetan Plateau during the past 50 years of climate change. Journal of Resources and Ecology, 5(2): 123-131.

Maidment D R, 1993. Handbook of Hydrology. New York: McGraw-Hill.

Meybeck M, 1987. Global chemical weathering of surficial rocks estimated from river dissolved loads. American Journal of Science, 287(5): 401-428.

Ministry of Environmental Protection, 2002. Environmental Quality Standard for Surface Water, GB 3838-2002. Beijing.

Piper A M, 1944. A graphic procedure in the geochemical interpretation of water analyses. Eos, Transactions American Geophysical Union, 25(6): 914-923.

Shi W G, 1995. Impact of yangzhuoyong lake hydropower on ecological environment in Tibet. Journal of Lake Sciences, 7(2): 178-184. (in Chinese)

Smolders A J P, Hudson-Edwards K A, Van der Velde G et al., 2004. Controls on water chemistry of the Pilcomayo river (Bolivia, South-America). Applied Geochemistry, 19(11): 1745-1758.

Song C Q, Huang B, Ke L H et al., 2014a. Remote sensing of alpine lake water environment changes on the Tibetan Plateau and surroundings: A review. ISPRS Journal of Photogrammetry and Remote Sensing, 92(2): 26-37.

Song C Q, Huang B, Ke L H et al., 2014b. Seasonal and abrupt changes in the water level of closed lakes on the Tibetan Plateau and implications for climate impacts. Journal of Hydrology, 514: 131-144.

Song C Q, Huang B, Richards K S et al., 2014c. Accelerated lake expansion on the Tibetan Plateau in the 2000s: Induced by glacial melting or other processes? Water Resources Research, 50(4): 3170-3186.

Stein M L, 1999. Interpolation of Spatial Data: Some Theory for Kriging. New York: Springer.

Sun R, Zhang X Q, Sun Y et al., 2013a. SWAT-based streamflow estimation and its responses to climate change in the Kadongjia River watershed, southern Tibet. Journal of Hydrometeorology, 14(5): 1571-1586.

Sun R, Zhang X Q, Tian Y, 2012a. Spatial differentiation of water chemical property in Yamzhog Yumco, South Tibet. Environment Science \& Technology, 35(11): 16-20. (in Chinese)

Sun R, Zhang X Q, Wu Y H, 2012b. Major ion chemistry of water and its controlling factors in the Yamzhog Yumco Basin, South Tibet. Journal of Lake Sciences, 24(4): 600-608. (in Chinese)

Sun R, Zhang X Q, Zheng D, 2013b. Spatial variation and its causes of water chemical property in Yamzhog 
Yumco Basin, South Tibet. Acta Geographica Sinica, 68(1): 36-44. (in Chinese)

Tian Y, Yu C Q, Luo K L et al., 2015. Hydrochemical characteristics and element contents of natural waters in Tibet, China. Journal of Geographical Sciences, 25(6): 669-686.

Tian Y, Zhang X Q, Sun R, 2012. Extracting alpine lake information based on multi-source and multi-temporal satellite images and its uncertainty analysis. Journal of Glaciology and Geocryology, 34(3): 563-572. (in Chinese)

Tibet Statistical Bureau, 2015. Tibet Statistical Yearbook in 2014. Beijing: China Statistics Press. (in Chinese)

Wang J B, Ju J T, Zhu L P, 2013. Water chemistry variations of lake and inflowing rivers between pre- and post-monsoon season in Nam Co, Tibet. Scientia Geographica Sinica, 33(1): 90-96. (in Chinese)

Wang S M, Dou H S, Chen K et al., 1998. Lakes of China. Beijing: Science Press. (in Chinese)

Winston R B, 2000. Graphical User Interface for MODFLOW Version 4. U.S. Geological Survey.

$\mathrm{Wu} \mathrm{W} \mathrm{H}, 2016$. Hydrochemistry of inland rivers in the north Tibetan Plateau: Constraints and weathering rate estimation. Science of The Total Environment, 541: 468-482.

Xiao J, Jin Z D, Ding H et al., 2012a. Geochemistry and solute sources of surface waters of the Tarim River Basin in the extreme arid region, NW Tibetan Plateau. Journal of Asian Earth Sciences, 54/55: 162-173.

Xiao J, Jin Z D, Zhang F et al., 2012b. Major ion geochemistry of shallow groundwater in the Qinghai Lake catchment, NE Qinghai-Tibet Plateau. Environmental Earth Sciences, 67(5): 1331-1344.

Yan L, Zheng M, 2015. Influence of climate change on saline lakes of the Tibet Plateau, 1973-2010. Geomorphology, 246: 68-78.

Yao Z J, Wang R, Liu Z F et al., 2015. Spatial-temporal patterns of major ion chemistry and its controlling factors in the Manasarovar Basin, Tibet. Journal of Geographical Sciences, 25(6): 687-700.

Ye Q H, Zhu L P, Zheng H X et al., 2007. Glacier and lake variations in the Yamzhog Yumco basin, southern Tibetan Plateau, from 1980 to 2000 using remote-sensing and GIS technologies. Journal of Glaciology, 53(183): 673-676.

Yu S M, Liu J S, Yuan J G, 2010. Vegetation change of Yamzho Yumco Basin in southern Tibet based on SPOT-VGT NDVI. Spectroscopy and Spectral Analysis, 30(6): 1570-1574. (in Chinese)

Zang Y L, Wang J L, Tian L D et al., 2014. The spatial distribution of stable isotopes in Yamzho Yumco Lake. Journal of Southwest University, 36(4): 127-132 (in Chinese)

Zhang G Q, Xie H J, Kang S C et al., 2011. Monitoring lake level changes on the Tibetan Plateau using ICESat altimetry data (2003-2009). Remote Sensing of Environment, 115(7): 1733-1742.

Zhang G Q, Yao T D, Xie H J et al., 2014a. Lakes' state and abundance across the Tibetan Plateau. Chinese Science Bulletin, 59(24): 3010-3021.

Zhang Q G, Kang S C, Wang F Y et al., 2008. Major ion geochemistry of Nam Co Lake and its sources, Tibetan Plateau. Aquatic Geochemistry, 14(4): 321-336.

Zhang X, Wu Y H, Zhang X, 2014b. Water level variation of inland lakes on the south-central Tibetan Plateau in 1972-2012. Acta Geographica Sinica, 69(7): 993-1101. (in Chinese)

Zhang X Q, Sun R, Zhu L P, 2012. Lake water in the Yamzhog Yumco Basin in South Tibetan region: quality and evaluation. Journal of Glaciology and Geocryology, 34(4): 950-958. (in Chinese)

Zhe M, Zhang X Q, Sun R et al., 2016. Assessment of water quality and the pollution factors of waters in Yamzhog Yumco Basin, Tibet. Journal of Lake Sciences, 28(2): 287-294. (in Chinese)

Zheng M P, Liu X F, 2009. Hydrochemistry of salt lakes of the Qinghai-Tibet Plateau, China. Aquatic Geochemistry, 15(1-2): 293-320.

Zheng W, Yao T D, Xu B Q et al., 2008. Ionic chemistry in snowpits from Yamzhog Yumco Basion. Environmental Science, 29(6): 1488-1494. (in Chinese)

Zhou S Q, Kang S C, Gao T G et al., 2010. Response of Zhadang Glacier runoff in Nam Co Basin, Tibet, to changes in air temperature and precipitation form. Chinese Science Bulletin, 55(20): 2103-2110.

Zhu L P, Ju J T, W J B et al., 2006. Environmental changes recorded in core sediments from the Pumoyum Co Lake of the Tibetan Plateau during the initial stage of the last deglacial period. Quaternary Sciences, 26(5): 772-780. (in Chinese)

Zhu L P, Ju J T, Wang J B et al., 2010a. Further discussion about the features of Lake Puma Yum Co, South Tibet, China. Limnology, 11(3): 281-287.

Zhu L P, Ju J T, Wang Y et al., 2010b. Composition, spatial distribution, and environmental significance of water ions in Pumayum Co catchment, southern Tibet. Journal of Geographical Sciences, 20(1): 109-120.

Zhu L P, Xie M P, Wu Y H, 2010c. Quantitative analysis of lake area variations and the influence factors from 1971 to 2004 in the Nam Co basin of the Tibetan Plateau. Chinese Science Bulletin, 55(13): 1294-1303. 